\title{
Using Authentic Materials to Improve Listening Comprehension in Esl Classroom
}

\author{
Moh. Farid Maftuh ${ }^{1}$, Imam Mudofir ${ }^{2}$, Muhyiddin Aziz $^{3}$, Eda Maaliah ${ }^{4}$, Nafik Fitriana $^{5}$ \\ Politeknik Negeri Madiun, Madiun East Java Indonesia ${ }^{1,2,3,4}$ \\ Universitas Wahidiyah, Jalan KH. Wachid Hasyim, Kediri East Java Indonesia ${ }^{5}$
}

\{mohfaridm@pnm.ac.id $\left.{ }^{1}\right\}$

\begin{abstract}
This research purposes is, to identify and prove whether the implementation of authentic material was able to improve the students' listening skills. The research method used in this study was a classroom action research (CAR). It was performed in two cycles at the ESL Classroom especially in the intermediate listening class. The procedures in every cycle included planning, implementing, observing, and reflecting. Qualitative data was collected by using observation, interview, and questionnaire. Analysing data by comparing the mean score of pre-test and post-test was as a quantitative data. The research findings prove that authentic materials improve the students' listening skill. It was demonstrated by the improvement of students' mean score. The mean score of pre-test was 58,38 . It improved to 70.15 in first post-test and improved up to 82,82 in second post-test. The improvements of students' listening comprehension are: 1) the students could locate and determine the general information (central idea), 2) the students could discover the detail information, 3 ) the students could find the implicit information, 4) the students could find the purpose, and 5) the students were able to make inference. In order to get maximum achievement of students listening comprehension, the lecturer ought to apply authentic material as an interesting teaching media which will seize students' attention to participate in listening comprehension.
\end{abstract}

Keywords: Listening Comprehension, Authentic Materials, ESL Learner, Car

\section{Introduction}

Listening has essential function in language teaching. It additionally has outstanding significance in foreign language classroom. Listening comprehension is a complicated process, fundamental in the improvement of L2 competence. Listeners apply both bottom up processers (linguistic knowledge) and top-down techniques (background knowledge) to comprehend. Moreover listening is a fundamental ability in the first language acquisition and is integral in English as Second/Foreign Language (ESL/EFL) learning. This skill, in spite of its importance, has been allotted in adequate consideration in ESL/EFL teaching. Clearly listening is complicated and includes creating and adapting interpretations of the world inside a linguistic context that seldom allows repetition of input. This can be challenging sufficient in one's first language; in a second language it additionally needs that the listener alternate or 
adapt linguistic competence to be applied in lecture rooms to enhance the listening comprehension of students in the vocational college.

In most English language instruction in Indonesia, however, the method of the teaching listening is no longer emphasized in spite of a large access to listening materials with accompanying audio visual technology in the classroom. Consequently, college students attribute their challenge in listening comprehension either to their insufficient competence or to the linguistic problem of stimulus texts. In a discussion of related teaching contexts, Graham (2006) observes that persevering with concern in improving listening abilities might also lead to a sense of passivity, lack of motivation and a much less effective listener. The factor right here is that the procedure of listening ability practise is not given enough interest in the lecture room and is undervalued globally and in Indonesia, in particular.

The proposed solution toward these cases mentioned above is through adapting the authentic materials in teaching listening. The authentic materials implementation in teaching English for ESL classroom, particularly in teaching listening, has turn out to be famous issue in latest years. This due to the challenge that listening need to have a connection to the actual listening life. Furthermore, the edited materials that are proposed for teaching listening abilities in the ESL classroom do not present the actual situation of the language. For instance, when learners hear to a recorded listening materials, the speech used is more formal which is not portray what generally seems in a daily conversation as it is attended for laboratory practice only.

The purpose of the use of authentic materials in the English language teaching lecture room is to make close contact with the goal language as lots as possible Berardo. It has meaning that learners are supposed to have experience of how the language in the actual situation. Align with this Nuttal point out that authentic textual content can be motivating due to the fact they are proof that the language is used for actual existence functions through actual people. Moreover authentic materials textual content are tremendous for all learner, not only to advance level, if the model of the material is adjusted to their level of language proficiency Morrison. Therefore in teaching listening abilities lecturers do not solely matter on the organized texts, however additionally search and discover a range of materials which expose the actual environment, up to date and suitable for students.

This research is emphasized on the students' listening comprehension in which supported with pre questionnaire in the field. Based on the informal observation before proposing this concept it can be stated that most of college students prefer to learn about listening through the use of the variative media tailored from authentic materials which it used to be interesting than other media of learning. Students prefer to get the up to date records relate to the actual situation in the field.

Based on the issues above, it was once performed a research to enhance the listening comprehension through the use of authentic materials in teaching listening in ESL classroom through Classroom Action Research (CAR). It is an exercise which attempt a concept in an exercise or actual situation in which predicted could enhance students' listening comprehension ability.

\section{Concept of Authentic Materials}

According to Dewi Authentic materials is one of the appropriate materials that can be used in teaching listening comprehension classroom. Authentic materials are materials made 
through native speakers that can be used in instructing and studying process however no longer in simple terms designed for teaching.

Widdowson in Gilmore sees authentic materials as language samples no longer developed for the reason of language learning. Underwood in Ahmadi, offers a clear definition of authentic materials when she stated that any textual content is "authentic". if it is produced in response to actual life communicative needs instead than an imitation of actual life communicative needs. "The term can be used to any sort of text, composed or spoken. The expression "authentic" to allude to language tests that reflect an effortlessness of structure, and a fittingness of social and situational setting that can be found in the language as utilized through the local speakers of English" [3].

The actual language and actual world duties allow college learners to know the relevance of lecture room pastime to their wide acces communicative goals. If you introduce natural texts (for a listing of actual world texts) instead than concoted, synthetic material, college students will extra effortlessly dive into the activity [4]. To conclude, authentic materials can be stated to be the type of materials which are used with the aid of native speakers, speaking orally or in writing, and which are no longer simplified for FL/SL getting to know purposes.

Several professionals declare that authentic materials are essential to use. According to Shrum and Glisan in [5], "authentic materials supply an wonderful potential for providing actual language, integrating culture, and heightening comprehension". They convey two motives for believing that authentic materials are beneficial. Firstly, by way of exposure to such materials, college students used to be be supplied with the chance to see language as it is used in actual world to serve a actual purpose. Secondly, such materials can be regarded as a prosperous source of cultural content. Bacon and Finnemann in [6] point out that the use of authentic materials are endorsed for each cognitive and affective reasonsm. The author, Jane Crawford in [5] explains the significance of advantageous teaching materials in her article; The Role of Materials in the Language Classroom: Finding the balance. According to Crawford, language is practical and have to be contextualised. The writer believes that it is not possible to recognize the actual meaning of any interaction without understanding who the contributors are or their social distance from the event refers to. For instance, a video drama needs to aid language in a meaningful way. Hence, the instructor is accountable for the stability performed between input and reapplication. Gilmore believes that if the purpose in the lecture room is to put together students for impartial language use, then definitely we had been obliged at some stage to present them with practical models of discourse [1]. The contents that faster the college students are uncovered to proper language, the greater swiftly they used to be study that comprehension is not a feature of understanding each word, however alternatively of creating techniques which is vital in each oral and written conversation [7]. [8] Additionally value the usage of authentic materials considering the fact that they accept as true with that extracting actual information from a actual textual content in a new or different language can be extraordinarily motivating.

\section{Methodology}

The research method used here was a classroom action research (CAR). It happens thru a dynamic and complementary technique which consists of 4 basic steps in a cycle. Each procedure has 4 steps: plan, act, observe and reflect [9].

There were two datum which were gathered in this research; they were quantitative data and qualitative data. Quantitative data was in the structure of listening test score. In this case, 
the preliminary test was once given to know the college students listening comprehension skills. It was executed before doing the action research. The pre-test was before doing the treatment in the first cycle. Meanwhile the post test was performed in each cycle to know the students' listening achievement. In the other hand, the qualitative data consists of the learning enthusiasm in the teaching learning process. It contents of questionnaire, interview and observation.

\section{a) Using Test}

There was be several times to check the students' listening proficiency, once before the action research, twice in first cycle and once in second cycle. In cycle 1, first of all the researcher provide the pre test. It is usually going to be conducted before doing the treatment. Next, the post test is given by the researcher after doing the special treatment in the first cycle. Then, the post test was held in cycle 1 and 2 to know the students' listening achievement.

\section{b) Questionnaire}

The questionnaire was used to discover students responds toward using authentic amterials to enhance students listening comprehension. The informations got as the reasons to revise the planning. The questionnaire held in twice. It was held in purpose to see the students' listening comprehension skills in collaborating the English lesson in or out of a classroom. It was done by the researcher before and after doing the action research related to the problems. The effects of questionnaires was modified into quantitative data by implementing Likert Scale. The classification of the motivations level toward teaching learning process is witten as follows: $0 \%-20 \%$ : very low, $21 \%$ - $40 \%$, low, $41 \%$ - $60 \%$ middle, $61 \%$ - $80 \%$ good, $81 \%$ $100 \%$ excellent.

\section{c) Interview}

Interview also was held to know the learning difficulties faced by students in the ESL classroom.

\section{d) Observation}

The observation was recorded and reported the teaching learning process, college students and lecturer's interaction, the attentions of college students during teaching learning activities in the class. The observation was conducted to see the student's response to AM media, and students' listening proficiency. It was conducted by observing the situation of learning in the classroom. Audiovisual recording and images have been additionally taken in the course of the implementation of the research to provide more accurate data. The data used to be collected in this study consists of information received in pre-research from the lecturer of listening class, the learning acitivities and the result of CAR implementation. 


\section{Research Findings}

\subsection{Identifying the Problem}

The writer did some observations to know pre conditions before the action research. There were some problems found that the students face in listening class. Firstly, the observation was conducted by interviewing the second semester students of English Department in order to know the problems in listening class. Secondly, the observation was conducted by giving questionnaire. The observation next was conducted in the listening class during teaching learning process. Pre-test was implemented to measure the level of listening comprehension of learners before implementing AM as the learning media.

Based on the interviewing of the second semester students of English department, the researcher found some points:

a. There were $60.7 \%$ from 28 students who got difficulties in recognizing the word meaning, finding main idea (central idea) and detail information, finding reference, also making inference.

b. There were $67.8 \%$ students did not accustomed to listen English in their daily life. This made them hard to understand what the speaker said.

c. There were $53.6 \%$ students had difficulties on understanding the purpose and basic context of short conversation when the conversational responses are indirect or difficult to predict or when the vocabulary is difficult.

d. There were $78.6 \%$ students could not understand detail in short talks when languages is syntacticaly complicated or some of them got difficult to understand the vocabs. They did not usually understand detail that include negative construction.

e. There were $57.1 \%$ students did not understand the details in longer conversations when the requested information is listened in the middle of of the text. They were unable to catch the meaning from paraphrased information or difficult grammatical constructions.

The researcher also gave the questionnaire about listening class for the second semester students at English Department of PNM. The researcher found out some problems dealing with listening comprehension:

a) There were $42.8 \%$ from 28 students who could not answer the questions based on listening material correctly.

b) There were $53.6 \%$ students could not find the general information on the listening material.

c) There were $75 \%$ students could not find the detail information

d) There were $67.8 \%$ students could not find the implicit information based on context of the listening material

e) There were $57.1 \%$ students could not find the purpose of the listening material

f) There were $50 \%$ students could not take summarize to the content of the listening material. There were some aspect in describing students' listening skills. Some students still feel that listening was the hardest skills. It was the first aspect. They discover troubles in transferring ideas into answer sheet. The second aspect was identifying the main ideas. Based on the pre test it was found that there some mistaken in identifying general information. Student could not capture what the narrator generally talked about. Not only that case, the students also made mistake in identifying specific informations about textual content. Moreover, the college students can't discover the implicit records primarily based on context of the listening material. The college students ought to not locate the cause of short spoken exchange throughout a wide range of vocabulary, even when conversational responses are indirect or not 
easy to predict. Furthermore, the college students could not summarize the material of the listening.

After finding the problems faced by students in listening intermediate class, the researcher carried out a pre-test to measure the students listening comprehension. It was also to find the data about their listening scores before actuating the CAR. The average of pre-test was 58.38. Based on the pre leminary study (observation) carried out in the first time and pretest conducted, it could be identified that the learners' listening mastery was still poor. It should be improved by implementing teaching media that can overcome the problems. The researcher used authentic material to improve students listening comprehension in implementing the teaching learning activity. The improvement of students listening comprehension was the goal of this research which concerns with some elements of listening such as finding central thought or main topic, detail info, implicit info based on context, purpose, summary of listening materials. Below is the table which shows the students' mean score in pre-test, post test 1 , and post test 2 .

Table 1. Score in pre-test, post test 1 , and post test 2

\begin{tabular}{ccc}
\hline \multicolumn{3}{c}{ Student's listening comprehension score } \\
\hline Pretest & Posttest 1 & Posttest 2 \\
58.38 & 70.15 & 82.28 \\
\hline
\end{tabular}

The table above showed that the students' mean score in Utterance is 3 . The table above confirmed that the college students' average score in pre-test is 58.38 which is categorized as poor, in opposite the students' mean/average score in post test 1 is 70.15 which is categorized as fairly good and then the score in post test two is 82.28 which is labeled as excellent. It could said that the average of students' score in listening comprehension enhanced from the pre-test to the first post-test and the last post-test. It indicated that authentic materials implementation was effective to increase/improve college students' listening comprehension.

Based on the data above, it could be concluded that there was the improvement between before implementing $\mathrm{AM}$ in teaching listening and after giving treatment in teaching listening. In other word, teaching listening through authentic materials were really able to improve the students listening comprehension.

\subsection{The Result of Action Research}

There were five aspects as the result of the research, they were discussed as follows:

a. Authentic materials can enhance college students listening comprehension in finding the general information (central idea). The findings of the research showed, there were a few learner who stil made a mistake in identifying the central idea. The learners could understand the content of the authentic materials. At least after listening the video they can catch the meaning of what actualy generall discussed about in the learning materials.

b. Authentic materials can improve students listening comprehension in finding the detail information. The result of this research indicated that the ESL learners stiil got few trouble in determing the explicit informations of the short text consist of setting time and place, character and situation by watching the video. It means that this is in line with Ur's theory. She said that environmental clues are often more likely to provide information about situation, geneal milleu and also speakers than about actual topic of discourse. Also in ESL classroom environment are normally represented by visual materials which are thus essential to the effective presentation of most listening exercises [10]. 
c. Authentic materials can improve students listening comprehension in finding implicit information based on context of listening material. This statements are supported by the other writer who tells about inferred meaning comprehension included implicit understanding and drawing inference from inout texts. The information required is not clearly stated, the listener must go beyond the surface information to see other meanings, which are not explicit stated in the text[11].

d. Authentic materials could improve lsitening comprehension of the learner in finding the purpose of the listening material. This in line with the statement of the other writer which tells about having a purpose for listening helps learners listen more effectively. For instance when listening to weather report, if the purpose is to decide wear a coat, the focus is on the temperature. In this study, lecturer explained to the learners which the prupose of the activity was. Students could listen for central idea, detail and make inference [12].

e. Authentic materials could enhance learners's listening comprehension in summarizing or inferencing the content of the listening material. As stated by Galeano, he said that drawing inferences and summarise were applied to improve learners' interest and help them to activate a set of expectations to interpret what was heard and anticipate what was coming next. Then the learners were exposed to the first screentshot which appeared on a video, after that they were asked to make inference [13]. This is in line with Allen explanation that by implementing authentic materials in the form of video, we can add moving pictures to soundtrack, the example is more comprehensive too. They could put the ways of people communicate visually as well as verbally. It can be dtermined that video is good means of bringing slice of living language into ESL Classroom [14].

\section{Conclussion}

Based on the data obtained, it could be concluded that authentic materials (AM) could improve the students' listening comprehension. The findings had been 1) the college students could find the general information, 2) the college students could discover the detail information, 3) the college students could locate the implicit information primarily based on context of the listening material, 4) the college students could discover the purpose of the listening material, and 5) the college students could precis the content material of the listening.

All the statements above is strengthened by the results of average score (mean). It was really improve significantly from the pre-test to the second cycles posttest. The average of learners' score achievement in the pretest was 57.07, then in the first cycle test or posttest the ESL learners got 73.17. actually there were already sigficant result of he test, but the lecturers wanted to maximize the potentials which could be achieved. So he conducted the second posttest and the average was 82.28 . In the pre-test, there were only $21.42 \%$ students who could pass the standard grade 65.00. After the research that was in the cycle 2 test, there were $92.85 \%$ students who reached the standard score/passing grade. Based on data above, it could be concluded that authentic material were rally able to improve the students' listening skills.

\section{Suggestion}

Based on the data of research finding, the writer want to present some suggestion interconnected with teaching listening and the implemenation of authentic materials learing media (AM). 


\section{a) For the Lecturer}

One of the most hard subject for students is Listening. Occasionally learners complain when the have assignments related to listening. It relates with the learning media used by lecturer. Creating joyful learning by proposing AM as the learning media could be an effective alternative way to improve learner's listening comprehension. It could be accomplished through the use of the appropriate media in teaching learning process unless the college students were getting bored then failed. By the use of authentic material, the student was attracted to join listening class. Automatically the teaching and learning method can run properly and the goals can be achieved.

\section{b) For the Students}

Not only lecturer who have great role as fasilator in the teaching and learning process but also students takes an important role as active learners. Nowdays there are many learning media sources which can be adopted as authentic materials from over the internet, like VOA, BBC, British Council, and Effortless English. Students can do it by themselves. The do not merely study in the class or in language laboraory but they must be active studying everywhere they want. They can broadly access based on the need of study and the level of understanding.

\section{c) For Institution}

For PNM, it needs to provide some facilities and media to support the teaching and learning process. The improvement of complete facilities and learning media would be helpful not only for the students but also for lecturers in enhancement of the language skills especially for receptive skills like listening.

\section{d) For Other Researcher}

There were still many weakneses and gaps in this stuudy which can be taken deeper for the other researcher for further research.

Table 1. Appendix A. Questionnaire for Students

\begin{tabular}{llcccc}
\hline No. Questionnaire & Strongly Agree & Agree & Disagree & Strongly Disagree \\
\hline $1 \quad \begin{array}{l}\text { I tend to use English authentic } \\
\text { materials than listen to non } \\
\text { authentic materials }\end{array}$ & & $73 \%$ & $3 \%$ & $2 \%$ \\
2 I tend to use simplified listening \\
materials provided in the non \\
authentic materials
\end{tabular}




\begin{tabular}{|c|c|c|c|c|c|}
\hline No. & Questionnaire & Strongly Agree & Agree & Disagree & Strongly Disagree \\
\hline 6 & $\begin{array}{l}\text { The authentic materials } \\
\text { listened in class are easier than } \\
\text { non-authentic materials. }\end{array}$ & $9 \%$ & $15 \%$ & $50 \%$ & $26 \%$ \\
\hline 7 & $\begin{array}{l}\text { The authentic materials I } \\
\text { listened in class are more } \\
\text { interesting than non-authentic } \\
\text { materials. }\end{array}$ & $29 \%$ & $55 \%$ & $9 \%$ & $7 \%$ \\
\hline 8 & $\begin{array}{l}\text { Authentic listening materials } \\
\text { enable me to comprehend other } \\
\text { materials outside the } \\
\text { class. }\end{array}$ & $41 \%$ & $27 \%$ & $18 \%$ & $14 \%$ \\
\hline 9 & $\begin{array}{l}\text { Authentic listening materials, in } \\
\text { the listening course motivate me to } \\
\text { listen to other materials outside the } \\
\text { class. }\end{array}$ & $21 \%$ & $58 \%$ & $15 \%$ & $6 \%$ \\
\hline 10 & $\begin{array}{l}\text { The process of teaching learning } \\
\text { introduces me to how language is } \\
\text { used in the real world. }\end{array}$ & $60 \%$ & $26 \%$ & $10 \%$ & $4 \%$ \\
\hline 11 & $\begin{array}{l}\text { Authentic listening materials } \\
\text { introduce me to how language is } \\
\text { used in the real world. }\end{array}$ & $61 \%$ & $25 \%$ & $10 \%$ & $4 \%$ \\
\hline 12 & $\begin{array}{l}\text { Authentic listening materials } \\
\text { improve my language proficiency } \\
\text { more than those ones. }\end{array}$ & $22 \%$ & $41 \%$ & $22 \%$ & $15 \%$ \\
\hline 13 & $\begin{array}{l}\text { Authentic listening materials } \\
\text { improve my listening } \\
\text { comprehension achievement }\end{array}$ & $25 \%$ & $55 \%$ & $15 \%$ & $5 \%$ \\
\hline 14 & $\begin{array}{l}\text { Authentic listening materials } \\
\text { increase my knowledge of } \\
\text { vocabulary items, which I } \\
\text { need in real situations. }\end{array}$ & $70 \%$ & $17 \%$ & $8 \%$ & $5 \%$ \\
\hline 15 & $\begin{array}{l}\text { Authentic listening materials } \\
\text { increase my familiarity with } \\
\text { the different rate of delivery in } \\
\text { their original context. }\end{array}$ & $67 \%$ & $21 \%$ & $7 \%$ & $5 \%$ \\
\hline 16 & $\begin{array}{l}\text { Authentic listening materials are } \\
\text { help me to get use to listen } \\
\text { to reduced form of word. }\end{array}$ & $22 \%$ & $62 \%$ & $10 \%$ & $6 \%$ \\
\hline 17 & $\begin{array}{l}\text { Authentic listening materials are } \\
\text { help me to get use to listen to } \\
\text { retain chunk of language in } \\
\text { short term memory }\end{array}$ & $34 \%$ & $46 \%$ & $11 \%$ & $9 \%$ \\
\hline 18 & $\begin{array}{l}\text { Authentic listening materials bring } \\
\text { new atmosphere in } \\
\text { teaching and learning process }\end{array}$ & $77 \%$ & $18 \%$ & $4 \%$ & $1 \%$ \\
\hline 19 & $\begin{array}{l}\text { Authentic listening materials } \\
\text { increase my motivation to learn } \\
\text { deeply about listening }\end{array}$ & $69 \%$ & $22 \%$ & $6 \%$ & $3 \%$ \\
\hline 20 & $\begin{array}{l}\text { What medium do you use most } \\
\text { often to obtain authentic } \\
\text { listening material? }\end{array}$ & & & & \\
\hline & TV & $8 \%$ & $4 \%$ & $73 \%$ & $15 \%$ \\
\hline
\end{tabular}




\begin{tabular}{|c|c|c|c|c|c|}
\hline No. & Questionnaire & Strongly Agree & Agree & Disagree & Strongly Disagree \\
\hline & & $4 \%$ & $6 \%$ & $63 \%$ & $27 \%$ \\
\hline & & $73 \%$ & $19 \%$ & $6 \%$ & $2 \%$ \\
\hline & & $67 \%$ & $23 \%$ & $7 \%$ & $3 \%$ \\
\hline
\end{tabular}

Table 2. Appendix B. The Test Result

\begin{tabular}{lccc}
\hline Nama Mahasiswa & Pre test & Post Test 1 & Post Test 2 \\
\hline Adelia SC & 53 & 70 & 72 \\
Agiel PM & 42 & 60 & 77 \\
Alvinta C & 58 & 80 & 85 \\
Annisa IS & 54 & 65 & 70 \\
Ardian A & 45 & 75 & 80 \\
Azahra WS & 62 & 75 & 78 \\
Cahya RC & 58 & 80 & 81 \\
Chantika S & 55 & 75 & 80 \\
Dany SA & 54 & 78 & 90 \\
Dea R & 57 & 70 & 76 \\
Dhea NA & 53 & 85 & 90 \\
Ervina A & 52 & 80 & 85 \\
Fifiana AT & 65 & 78 & 79 \\
Frans NW & 65 & 70 & 75 \\
Frisha DF & 60 & 70 & 78 \\
Kania AB & 65 & 85 & 89 \\
Khoirun NA & 53 & 73 & 87 \\
Lora SA & 57 & 72 & 90 \\
Maulidini I & 53 & 70 & 92 \\
Mohammad R & 62 & 76 & 89 \\
Nabila SH & 50 & 74 & 90 \\
Norisa A & 50 & 68 & 70 \\
Pradiatama TP & 65 & 74 & 90 \\
Retno DKS & 62 & 76 & 86 \\
Ridwan HA & 66 & 72 & 80 \\
Rifa M & 50 & 60 & 76 \\
Salma AKR & 67 & 68 & 85 \\
Ulinuhagustin C & 65 & 70 & 84 \\
Rata Rata Kelas (Mean) & 57,0714 & 73,1785714 & 82,2857143 \\
\hline
\end{tabular}

\section{References}

[1] A. Gilmore, "Authentic materials and authenticity in foreign language learning," Lang. Teach., vol. 40, no. 2, pp. 97-118, 2007, doi: 10.1017/S0261444807004144.

[2] S. M. Ahmadi, "An Investigation into the effect of authentic materials on improving intermediate EFL learners' pragmatic competence," Int. J. Res. English Educ. Vol., vol. 1 no. 1, pp. 38-42, 2016, [Online]. Available: http://ijreeonline.com/browse.php?a_id=27\&.

[3] C. V. Rogers and F. W. Medley, "Language With A Purpose: Using Authentic Materials in the Foreign Language Classroom," Foreign Lang. Ann., vol. 21, no. 5, pp. 467-478, 1988, doi: 10.1111/j.1944-9720.1988.tb01098.x.

[4] H.Douglas Brown, “[H._Douglas_Brown]_Teaching_by_Principles,_Second_(BookFi.org).pdf," Teaching 
by Principles An Interactive Approach to Language Pedagogy. p. 491, 2000.

[5] B. Mandasari, "Teachers ' Beliefs on the Use of Authentic English Education of Graduate Program Faculty of Teacher Training and Education," p. 219, 2015.

[6] R. C. Dewi, "Utilizing Authentic Materials on Students' Listening Comprehension: Does it have Any Influence?," Adv. Lang. Lit. Stud., vol. 9, no. 1, pp. 70-74, 2018, [Online]. Available: http://dx.doi.org/10.7575/aiac.alls.v.9n.1p.70.

[7] V. Baghban and Z. Zohoorian, "A Review on the Effectiveness of using authentic materials in ESP courses," English Specif. Purp. World, vol. 10, no. 31, pp. 1-14, 2011.

[8] W. Guariento and J. Morley, "Text and task authenticity in the EFL classroom," ELT J., vol. 55, no. 4, pp. 347-353, 2001, doi: 10.1093/elt/55.4.347.

[9] J. Francis, "The Action Research Concept," 1996.

[10] P. Ur, A Course in Language Teaching Training Foreign Language Teachers - A reflective approach. 1991.

[11] A. Thesis and F. Wulandari, "Improving Students ' Listening Ability Using Spot the Dictogloss Technique," [Online]. Available: https://core.ac.uk/download/files/478/16508708.pdf.

[12] B. Mandasari, "Teachers ' Beliefs on the Use of Authentic English Education of Graduate Program Faculty of Teacher Training and Education," 2015.

[13] M. Montoya Galeano, J. A. Toro López, and C. C. Vélez Quintero, "The Practice of the Listening Skill Through the Use of Authentic Material in a Fifth Grade Course from a Public School in Pereira," 2016.

[14] C. Brumfit, The Practice of Communicative Teaching. 1986. 